\title{
Oceanography Before Scripps
}

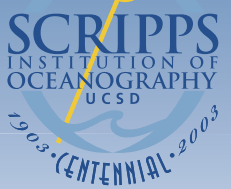

Eric L. Mills

Dalhousie University • Halifax, Nova Scotia, Canada

When George F. McEwen, a young physicist, came to La Jolla in 1912 as a full-time employee of William E. Ritter's laboratory of the Marine Biological Association of San Diego as its first physical oceanographer, he was told by his mentors at the University of Illinois that no such profession existed (Mills, 1990; Figure 1). There was a grain of truth in this assertion, for even the word "oceanography" did not have a clear professional definition then or for several decades to come. Indeed, Ritter's laboratory in La Jolla, under the wing of the University of California, came to be called the Scripps Institution for Biological Research beginning in 1912, and it was only in 1924, under a new director, Thomas Wayland Vaughan, that the laboratory was named the Scripps Institution of Oceanography. Oceanography as a professional specialization hardly existed even in 1930, when the Woods Hole Oceanographic Institution, the first sister institution to Scripps, was founded under the direction of Henry Bigelow on the East Coast of the United States. A strong case can be made that it was World War II that solidified a set of disparate approaches to the ocean into a profession and a suite of professional practices that recognizably characterize oceanography in a modern sense.

\section{The Ancients and the Oceans}

Interest in the oceans and in the properties of water are age old. Herodotus wrote that the Ionians, the predecessors of the Hellenic Greeks, living in cities along the coast of Asia Minor, had a strong interest in water and hydraulics-and for the most practical of reasons, the state of drought characteristic of the whole Mediterranean basin. As traders in the Black Sea, the Milesians had good practical need for knowledge of winds and currents. When Greek civilization spread west, partly through trade, partly due to the pressure of the Persian Empire from the east, the Mediterranean became well known, and so too, to certain groups of traders and adventurers, did the Atlantic. Homeric legend has it that the known world, what the early Greeks called oikumené, was surrounded by Okeanus, the world ocean. Written records exist of at least one voyage into the Atlantic by the fourth century BC, that of Pytheas of Massilia (modern Marseille), certainly as far north as the British Isles and Ireland and possibly as far as Norway or Iceland (Casson, 1991; Whitaker, 1981). This was not exceptional, as shown by the recent discovery of a Phoenician shrine to Hercules dating from the eighth century BC on the rock of Gibraltar, located where voyagers into the Atlantic could see it as they left the Mediterranean on trading voyages up the Atlantic coast. The only existing map from antiquity, dating from the first century BC, shows the geography of Spain, including much of its coast. Untutored traders and sailors undoubtedly knew more about the oceans than the geographers whose words and ideas have come down from ancient times mainly in the works of Plato, Aristotle, and the great mathematicians and geographers such as Eratosthenes (ca. 275-194 BC—see Harley and Woodward, 1987, for a review of his estimate of the size of the earth) and Claudius Ptolemy (ca. 90-168 AD).

Ptolemy is a case in point, for in his Geographia, dating from some time after $147 \mathrm{AD}$, there is a lengthy list of places in the expanding known world, located for the first time in a system of geographical coordinates, and a detailed consideration of how locations on a sphere (Earth) could be represented on a plane surface (i.e. the problem of map projections-Berggren and Jones, 2001). Most important for the future of ocean exploration, he gave detailed instructions for the construction of maps taking in all of the known worldand a good deal of the unknown as well.

\section{Ocean Exploration in the Middle Ages and Beyond}

Claudius Ptolemy's Geographia, which distilled the geographical knowledge of the ancient world, lay fallow for centuries, emerging in the Renaissance from Greek-Byzantine manuscripts that were soon exploited for their potential-to depict the world (including its oceans) graphically. German mapmakers in the early fifteenth century produced the first world map based on the authority of the ancients; other versions based upon Ptolemy's text soon followed (Whitfield, 1994). It mattered not that geographical knowledge in the fifteenth century was more extensive than Ptolemy's from thirteen centuries earlier: the maps were beautiful and they stimulated the imagination of traders and adventurers to explore the sea routes that could lead to the riches of the East-an imperative made all the more pressing by the difficulty of trading by land to the east once Constantinople fell to the Ottoman Turks in 1453. 


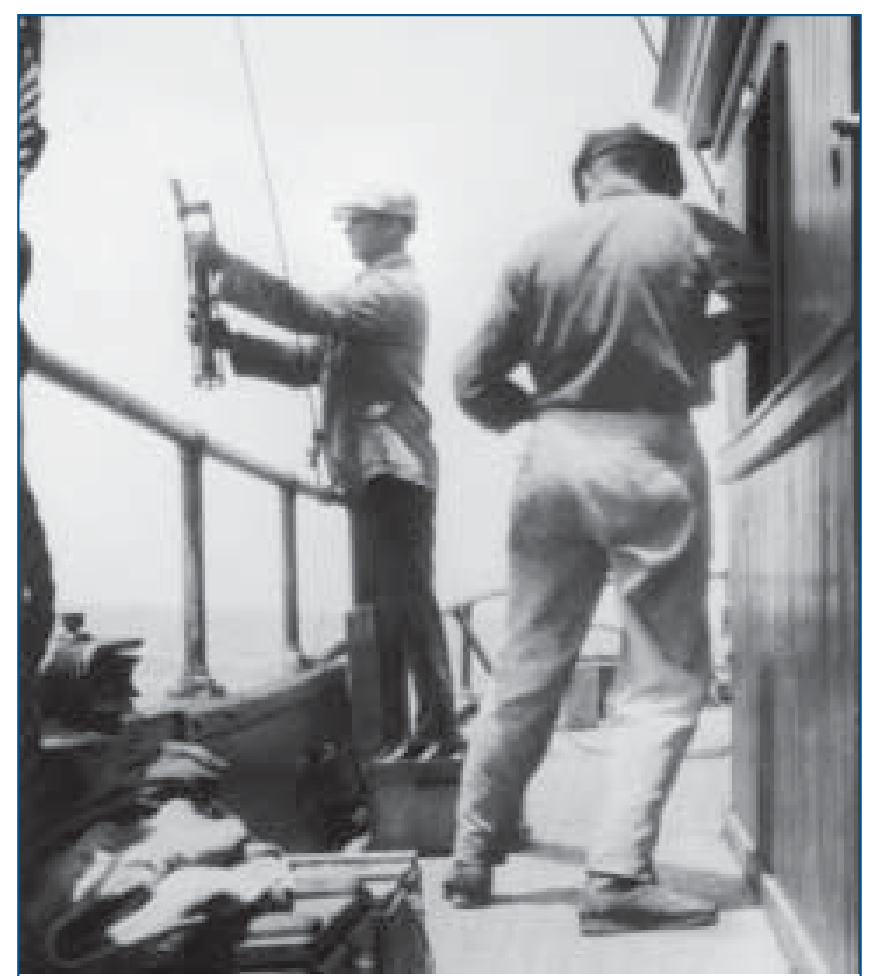

Figure 1. George F. McEwen (right) and Eric G. Moberg on a research cruise in 1925.

Portuguese voyages of trade and exploration, soon stimulated by the expanding slave trade from West Africa, opened the African coast to the Western imagination beginning about 1415, culminating in Vasco Da Gama's journey into the Indian Ocean from the southwest in 1497 and his arrival in India in May 1498. Only a generation later, 1519-1522, some of Ferdinand Magellan's crew completed the first circumnavigation of the globe, physically circumscribing both it and the oceans ${ }^{1}$ for the first time. From that time onward, both Earth and its oceans took on a recognizably modern form, in which the devil lay in the details rather than in the broad unknowns that faced ancient, medieval, and Renaissance geographers. From that time, and increasingly in the sixteenth and seventeenth centuries, the oceans came to play more than a supporting role in the expansion of geographical knowledge. In 1997, Margaret Deacon, a preeminent historian of oceanography, claimed that an expanded knowledge of the oceans required instruments for sampling, and most important, the desire to know more supported by financial resources (Deacon, 1997). ${ }^{2}$ From the eighteenth century onward, the oceans did indeed come to

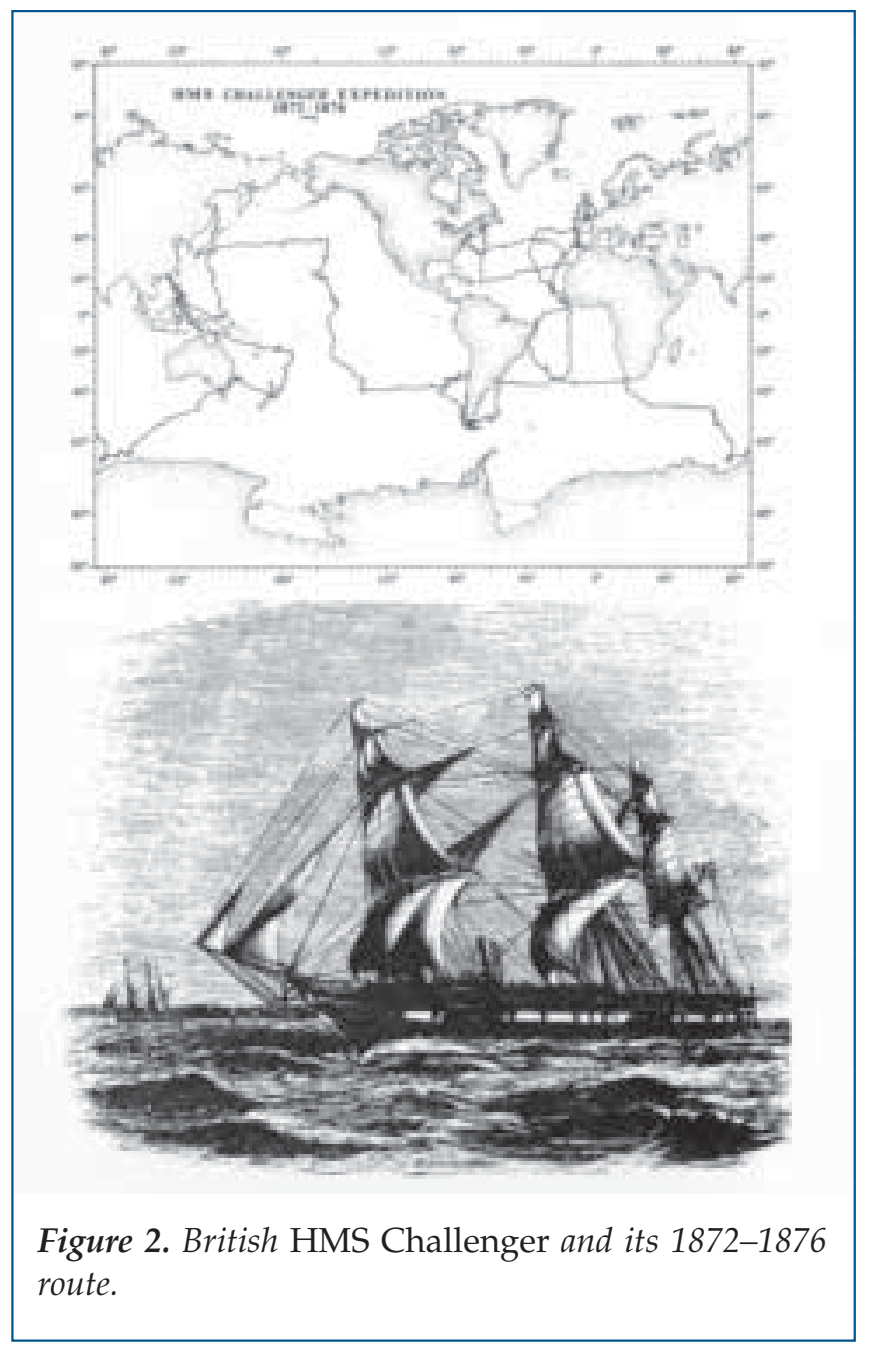

be plumbed at moderate depths using, especially, increasingly sophisticated thermometers and sounding devices (McConnell, 1982), but usually in the service of trade or the military rather than from the point of view of pure science.

The prospect of telegraph networks after the 1840s put a premium on the measurement of depths and knowledge of ocean sediments. The details of ocean currents and what caused them (the wind was the first suspect) occupied a few scientists until the end of the nineteenth century, but not in any systematic way, and quite independently of physics and any taint of mathematics. ${ }^{3}$ The fusion of mathematics with the study of ocean currents, called "dynamical oceanography" by its proponents, arose not in the more mainline scientific countries such as Britain and Germany, but out of Scandinavian concern with climatic fluctuations and their effects on fisheries and agriculture. ${ }^{4}$

${ }^{1}$ The role of the Portuguese Prince Henry "the Navigator" (1394-1460) as a great scholar of marine navigation is a myth (see Russell, 1984; Russell, 2000). The Indian Ocean, including its seasonally reversing winds and currents, had been known to Arab and Indian navigators for centuries (see Aleem, 1967; Warren, 1987; Peterson et al., 1996).

2See especially the introduction to her 1997 book, Scientists and the Sea 1650-1900: A Study of Marine Science.

${ }^{3}$ This area-the history of physical oceanography—is largely untouched by historians; however, see Burstyn (1971) and, more broadly, Mills (1999). ${ }^{4}$ For a review of treatment from a meteorological point of view, see Friedman (1989). 
A stereotypical and myopic view of the origin of oceanography is that it all came together-and beganwith the round-the-world voyage of the British corvette HMS Challenger from 1872-1876 (Figure 2). Challenger's voyage was the outcome of several decades of interest in the diversity of life by biologists, notably the possibility that the great question of how species originated and diversified (solved by mid-nineteenth century by Charles Darwin) could be answered by dredging deeper and deeper. The deep sea was envisioned as a refugium of the primitive species that could have given rise to the more complex ones found in shallow water and on land. ${ }^{5}$ The great voyage of Challenger could hardly have happened, however, without the involvement of the British physiologist W.B. Carpenter, who was involved in a bitterly fought dispute over the driving forces of ocean circulation, espousing density over the sole action of the wind (Deacon, 1993). Investigations during the Challenger voyage did not solve the problemwhich was in other, mathematically oriented hands in Scandinavia-but they did provide a rallying point for many kinds of marine scientists in the early twentieth century.

In 1903, when William E. Ritter's laboratory opened in the boathouse of the Hotel del Coronado in San Diego, Ritter was well aware of the prevailing currents of opinion in European marine science. He became even more aware of them after the visit of his Berkeley colleague Charles A. Kofoid to Europe in $1908 / 1909$ resulted in a synoptic survey of the many biological stations on that continent and their work (Kofoid, 1910). What he did not have was a single name for the study of the oceans, for reasons that my brief survey suggests: the variety of approaches that had been taken throughout time to the oceans and the lack of a single approach to study of the sea.

\section{Ocean Science Becomes "Oceanography"}

If there was a single thread throughout the ocean sciences early in Ritter's career, it was the thread of geography, and the dominant accent, despite the example set by Challenger, was German. Just as the approach of the ancients and Alexandrian astronomers, medieval travelers, and Renaissance scholars of Earth had been geographical, so too was the expanding field of ocean science in the mid- and late nineteenth century. This is evident especially in the most abundant literature of the field, which was German in origin. The word oceanography comes from German origins and was soon applied in a new way at about the time that Ritter was beginning to plan a marine biological station for the
California coast. In late nineteenth century Germany, scientific study of the oceans, Oceanographie or later Ozeanographie, was a branch of physical geography and concerned itself with the extent, depth and properties of the world's oceans and seas. The greatest authority was Otto Krümmel (1854-1912) who published three volumes of the Handbuch der Ozeanographie between 1887 and 1911 (von Boguslawski and Krümmel, 1897; Krümmel, 1907; Krümmel, 1911). These are notable for their descriptive approach to the oceans, and increasingly for the introduction of mathematical physics to geographers. They contain no biology whatsoever. It was from this geographical approach to the oceans that the word oceanography was introduced to English-speaking scientists by the Glasgow-based German chemist William (Wilhelm) Dittmar, who had studied the composition of the Challenger seawater samples. In a review, Dittmar (1883) introduced the word; in an encyclopedia article three years later, he used the word oceanographer (Dittmar, 1886).

The restriction of "oceanography" to the physical sciences extended well beyond the origins of Scripps Institution of Oceanography. W.A. Herdman (1858-1924) of the University of Liverpool, who in 1919 founded and occupied the first chair of oceanography in the Englishspeaking world, described oceanography as "the study of the sea in all aspects-physical, chemical and biological" (Herdman, 1923). His successor, however, James Johnstone (1870-1932) was more restrictive. Despite his background as a zoologist and fisheries biologist, Johnstone (1923) dealt with oceanography as physical geography in his text An Introduction to Oceanography. In 1926, he wrote of "the physical geography of the ocean-that is, the modern science of oceanography" (Johnstone, 1926). Examples like these show that there were no tight disciplinary boundaries surrounding "oceanography" and that etymologically and culturally, it owed much to the past. Thus the scientific world of the early Scripps Institution was a transitional one, in which the various branches of marine science had not come into stable relationships with each other, as indeed they would not for another forty years. ${ }^{6}$

To Ritter in 1903, the imperative need of marine biology was to understand the organism in its relations with other organisms and in relation to its environment. With a broad-mindedness unusual for a biologist at the time he looked to the physical sciences and mathematics for enlightenment. He came to believe that biologists could benefit by patterning their activities on astronomical observatories, in which teams of 
researchers contributed to a common goal. ${ }^{7}$ The physicist George McEwen's appointment was the first step in this direction. This interdisciplinary approach was, in a way certainly not foreseen by Ritter at the time, a step toward Scripps Institution of Oceanography, and a distinct and important break with the long tradition of marine explorations and the geographical tradition.

\section{References}

Aleem, A.A., 1967: Concepts of currents, tides and winds among medieval Arab geographers in the Indian Ocean. Deep-Sea Res., 14, 459-463.

Berggren, J.L. and A. Jones, 2001: Ptolemy's Geography: An Annotated Translation of the Theoretical Chapters. Princeton, New Jersey: Princeton University Press, xvii plus $192 \mathrm{pp}$.

Burstyn, H.L., 1971: Theories of winds and ocean currents from the discoveries to the end of the seventeenth century. Terrae Incognitae, 3, 7-31.

Casson, L., 1991: The Ancient Mariners: Seafarers and Sea Fighters of the Mediterranean in Ancient Times. Princeton University Press, Princeton, New Jersey, pp. 124-126.

Deacon, M., 1993: Wind power versus density differences. A 19th century debate about ocean circulation. Ocean Challenge 4(1/2), 53-60.

Deacon, M., 1997: Scientists and the Sea 1650-1900: A Study of Marine Science. Aldershot, England, Ashgate, xl plus $459 \mathrm{pp}$.

Dittmar, W., 1883: Proceedings of the Philosophical Society of Glasgow, 16, 56.

Dittmar, W., 1886: Encyclopaedia Britannica, 21, 613.

Friedman, R.M., 1989: Appropriating the Weather: Vilhelm Bjerknes and the Construction of a Modern Meteorology. Ithaca, New York, Cornell University Press, xx plus $251 \mathrm{pp}$.

Harley, J.B. and D. Woodward, eds., 1987: The History of Cartography: Vol. 1.: Cartography in Prehistoric, Ancient, and Medieval Europe and the Mediterranean. Chicago, University of Chicago Press, pp. 154-155.

Herdman, W.A., 1923: Founders of Oceanography and Their Work. London, Arnold, p.1.

Johnstone, J., 1923: An Introduction to Oceanography, with Special Reference to Geography and Geophysics. London, Hodder \& Stoughton, 351 pp.

Johnstone, J., 1926: A Study of the Oceans. London, Arnold, p. v.

Kofoid, C.A., 1910: The Biological Stations of Europe. Washington, DC, U.S. Bureau of Education, 360 pp.

Krümmel, O., 1907: Handbuch der Ozeanographie: I. Die räumlichen, chemischen und physikalischen Verhältnisse des Meeres. Stuttgart, Germany, Engelhorn, $526 \mathrm{pp}$.

Krümmel, O., 1911: Handbuch der Ozeanographie: II. Die
Bewegungsformen des Meeres. Stuttgart, Germany, Engelhorn, $766 \mathrm{pp}$.

McConnell, A., 1982: No Sea Too Deep: The History of Oceanographic Instruments. Bristol, England, Adam Hilger, ix plus $162 \mathrm{pp}$.

Mills, E.L., 1983: Problems of deep-sea biology: An historical perspective. In: G.T. Rowe ed., The Sea: Vol. 8. Deep-Sea Biology. New York, Wiley, pp. 1-79.

Mills, E.L., 1990: “Useful in many capacities.” An early career in American physical oceanography. Historical Studies In the Physical and Biological Sciences, 20(2), 265-311.

Mills, E.L., 1995: From marine ecology to biological oceanography. Helgoländer Meeresuntersuchungen, 49, 29-44.

Mills, E.L., 1999: De Motu Marium: Understanding the Oceans Before the Second Scientific Revolution. The Stillman Drake Lecture. Toronto, Canada: Canadian Society for the History and Philosophy of Science, $36 \mathrm{pp}$.

Mills, E.L. (2002). Exploring a space for science: The marine laboratory as observatory. Actas VII Congreso de la Sociedad Espanola de Historia de las Ciencias y de las Tecnicas I, pp. 51-57.

Peterson, R.G., L. Stramma and G. Kortum, 1996: Early concepts and charts of ocean circulation: Progress in Oceanography, 37, 1-115 (see esp. pp. 10-11).

Russell, P.E., 1984: Prince Henry the Navigator: The Rise and Fall of a Culture Hero. Taylorian Special Lecture, 10 November 1983. Oxford, England: Clarendon Press, $30 \mathrm{pp}$.

Russell, P.E., 2000. Prince Henry 'the Navigator': A Life. New Haven, Connecticut: Yale University Press, xvi plus 448 pp.

von Boguslawski and O. Krümmel, 1897: Handbuch der Ozeanographie: II. Die Bewegungsformen des Meeres. Stuttgart, Germany, Engelhorn, 592 pp.

Warren, B.A., 1987: Ancient and medieval records of the monsoon winds and currents of the Indian Ocean. In: J.S. Fein and P.L. Stephens, eds., Monsoons. New York, Wiley, pp. 137-158.

Whitaker, I., 1981: The problem of Pytheas' Thule. Classical Journal, 77(2), 148-164.

Whitfield, P., 1994: The Image of the World: 20 Centuries of World Maps. London: The British Library, chapter 1.

"For the implications of the metaphor "biological observatory," see Mills (2002). 